\title{
Evaluation of New Zealand's Trade and Direct Investment Intensities with Major Trading Partners
}

\author{
Satya Gonuguntla ${ }^{1}$ \\ ${ }^{1}$ Faculty of Business \& IT, Manukau Institute of Technology, Auckland, New Zealand \\ Correspondence: Satya Gonuguntla, Faculty of Business \& IT, Manukau Institute of Technology, PB 94006, 25, \\ Davies Ave, Manukau, Auckland-2241, New Zealand.
}

Received: May 15, 2017

Accepted: June 12, 2017

Online Published: June 23, 2017

doi:10.20849/abr.v2i2.161

URL: https://doi.org/10.20849/abr.v2i2.161

\begin{abstract}
New Zealand (NZ) has been implementing liberal economic policies since 1980s. Accordingly, NZ has negotiated Free Trade Agreements with several countries. NZ is also the founding member of the Asia Pacific Economic Co-operation (APEC) which aims to achieve sustainable economic growth and prosperity among the countries in the Asia-Pacific Region, through free trade, investment and rapid regional economic integration. The bilateral FTAs include the Closer Economic Relations Agreement (CER) with Australia in 1983, Singapore (2001), and China (2008), Malaysia (2010), Hong Kong, China (2011) which are also member economies of the APEC. The consequence is an increase in trade as well as investment flows from Australia, Japan, Singapore, USA, and China. Presently, Australia is the largest export destination for New Zealand accounting for about $20 \%$ of merchandise exports, and a similar percent of merchandise imports. Australia is also the largest investor in NZ accounting for $56 \%$ of FDI in New Zealand. Singapore is NZ's $6^{\text {th }}$ largest trading partner and China is the second largest trading partner. Singapore, and Hong Kong, China each account for $4.5 \%$ of NZ's FDI stock. The aim of this paper is to investigate the changing pattern of NZ's total trade with these countries and inward FDI stock from these countries. The methodology consists of calculating and interpreting the Trade Intensity Indices and FDI Intensity Indices to gauge the significance of these two ratios at bilateral and regional level.
\end{abstract}

Keywords: New Zealand, total trade, FDI, trade intensity indices, FDI intensity indices

JEL classification: F130, F210.

\section{Introduction}

Given the location and small market size, New Zealand(NZ), depends on international trade for economic growth and prosperity. The small domestic market implies limited economies of scale in the absence of external trade (Vitalis, 2009). New Zealand is endowed with natural resources consisting of land and climate that are suitable to produce primary products such as dairy, wool, meat and wine in which it tends to have high levels of comparative advantage. Studies have shown that NZs exports are dominated by primary products ie agriculture and food products (OECD, 2015; Lattimore, Kowalski \& Hawke, 2009). That dairy and meat products together account for $36 \%$ of the New Zealand's exports (Statistics NZ, 2015), and about $95 \%$ of milk produced in New Zealand is exported indicates New Zealand's heavy dependence on primary exports (DCANZ, 2016). Consequently, overseas markets play a significant role in consuming NZ's exports and contributing to its economic growth. Since the mid 80's New Zealand embarked on economic liberalisation policies, and as part of the liberalisation programmes, New Zealand has negotiated several Free Trade Agreements (FTAs) including with Australia, Singapore, China, Malaysia and Thailand. Evidence shows that as a consequence of these FTAs the trade flows between New Zealand and the partner countries have significantly improved (MFAT, 2005). NZ also is a member of Regional Trade blocks such as APEC, and the ASEAN-Aus-NZ FTA. In addition to increase in trade flows the liberalisation policies also attracted overseas investment into New Zealand mostly from countries with which New Zealand has trade relations. This paper examines the relationship between trade and direct investment intensities among New Zealand and its major trading partners within the APEC region that are also a major source of inward direct investment i.e. Australia, China, USA, Japan, Singapore, and Hong Kong (SAR). The aim is to examine whether the trade flows and inward FDI are diversified or concentrated only in a few countries. 
The paper is organised as follows: Section II presents the highlights of trade flows and direct investment stocks in New Zealand during the years 2001 to 2015. Section III consists of literature review, and Methodology is presented in Section IV. Results are discussed in Section V, and Section VI concludes.

\section{Trade Flows and Direct Investment Stocks}

The UK used to be New Zealand's major trading partner until the early 70 's accounting for about $70 \%$ of merchandise exports. When the UK joined the EU in early 70's, its importance as a major export market started declining, and at the end of year 2015 UK accounted only for 5\% of NZ's total external trade. As New Zealand diversified, and gained access to other markets consisting of mostly APEC member economies such as Australia and China, their share of total trade started increasing over a period of time. Similar pattern has emerged in terms of inward Foreign Direct Investment (FDI) into New Zealand. Total trade proportions between NZ and its major trading partners and FDI stocks are presented in Table 1.

Table 1. Total trade and FDI stock (\%): NZ and major trading partners

\begin{tabular}{lllll}
\hline \multirow{2}{*}{ Country } & \multicolumn{2}{c}{ Total trade (\%)** } & \multicolumn{2}{c}{ FDI stock (\%) } \\
\cline { 2 - 5 } & 2001 & 2015 & 2001 & 2015 \\
\hline Australia & $20.0 \%$ & $17.6 \%$ & $35.0 \%$ & $52.0 \%$ \\
\hline China & $5.3 \%$ & $16.1 \%$ & $0.003 \%$ & $0.007 \%$ \\
\hline USA & $15.4 \%$ & $12.1 \%$ & $15.6 \%$ & $8.2 \%$ \\
\hline Japan & $12.4 \%$ & $5.1 \%$ & $1.5 \%$ & $4.8 \%$ \\
\hline Singapore & $(\mathrm{NA})$ & $3.3 \%$ & $2.1 \%$ & $5.8 \%$ \\
\hline $\begin{array}{l}\text { Hong Kong } \\
\text { (SAR) }\end{array}$ & $2.6 \%$ & $1.1 \%$ & $0.01 \%$ & $5.2 \%$ \\
\hline UK* & $4.1 \%$ & $2.2 \%$ & $11.8 \%$ & $5.0 \%$ \\
\hline
\end{tabular}

* Not APEC member economy

** Total exports + Total imports (HS Code)

Source: Statistics New Zealand.

Although, Australia's share in NZ's total trade declined from $20 \%$ in 2001 to $17.6 \%$ by 2015 its share in FDI stock has increased from $35 \%$ to $52 \%$. In the post CER era, Australia has emerged as NZ's largest trading partner and also the largest source of FDI, which can be attributed to the geographical proximity, similarities in economic, legal, political and cultural environment. There has also been a three fold increase in China's share of total trade i.e. from $5.3 \%$ in 2001 to $16.1 \%$ in 2015 , highest increase among the key trading partners. The rise can be attributed to the FTA between the two countries negotiated in 2008, which liberalised the trade flows. At less than $1 \%$, the FDI from China to NZ is not significant (some of the data is classified as confidential). In the case of both USA, and the UK, there has been a decline both in total trade and FDI stock. Japan, Singapore, and Hong Kong recorded a substantial increase in FDI stock while showing a decline in the total trade. The percentage change in the absolute values of total trade and FDI stock show mixed results with no particular pattern. An attempt is made whether the trade, and FDI intensities exhibit a particular pattern to draw conclusions about the concentration or divergence of these two variables.

\section{Literature Review}

International trade and FDI are two important means for a country to connect with the rest of the world and be part of the global economy. In the current scenario of rapid globalisation, the degree of economic integration plays a significant role in enabling a country to achieve higher growth through trade and FDI, particularly for a small, geographically isolated country such as New Zealand. There is ample evidence in economic literature about the advantages of international trade and FDI. As part of economic liberalisation policies initiated in 1980s, the government of NZ negotiated several free trade agreements to gain access to new markets in order to 
increase trade, and attract investment. The most significant FTA negotiated by NZ is the Closer Economic Relations (CER) agreement with Australia in the year1983, aimed at relaxing both tariff and non-tariff barriers to accelerate trade and investment flows between the two countries. NZ is also a founding member of the APEC (1989) which aims to achieve sustainable economic growth and prosperity among the countries in the Asia-Pacific Region, through free trade, investment and rapid regional economic integration. Subsequently, NZ has signed FTAs with several countries that are also APEC member economies. These bilateral FTAs include, Singapore (2001), Thailand (2005), People's Republic of China (2008), Malaysia (2010), Hong Kong (2011), AANZFTA (2012), South Korea (2015). The logical conclusion would be that the free trade policies of the NZ government, coupled with the FTAs negotiated with the above mentioned APEC member economies would have resulted in greater degree of regionalism, and greater integration wherein a group of countries tend to trade more with each other than with others as they all are connected through geographical and institutional linkages. Michaely (2014), argued that regionalism is a result of commonalities such as geography, culture, language, or institutional arrangements leading to closer trade relations. In addition, the very process of globalisation contributes to the growth of regionalism. Dent (2013), emphasised that regionalism is closely linked to globalisation as the latter is all about connectivity, integration, and interdependence of various parts of the world taking place on a global scale then regionalism is a similar process happening at a regional level. Empirical evidence suggests that regional integration does lead to enhanced trade. Baldwin and Carpenter (2010) found that East Asia's trade with itself has increased from $25 \%$ to $40 \%$ on the import side between 190 and 2005 due to intra-regional integration. Hassan and Nassar (2016) in their study of the relationship between NAFTA and Mexico's key economic variables found that NAFTA had a positive impact on Mexico's exports. Given the potential advantages of regional integration, China also negotiated a Regional Economic Integration Agreement with ASEAN in 2010 (Wang, 2011). As mentioned earlier, NZ has also negotiated a FTA with ASEAN along with Australia i.e. ASEAN Australia NZ FTA (AANZFTA) in 2012.

In addition to trade, both inward and outward investment enable a country to become an integral part of the global economy. FDI strengthens NZ's competitive advantage and ability to innovate thus resulting in higher exports, and contributing to higher economic growth. Other benefits include efficient allocation of resources, introduction of new technology and management techniques that promote domestic competition and productivity growth. FDI has direct impact on NZ's prosperity not only through trade connections but also by increasing the employment opportunities through investment in local businesses (KPMG, 2015). Given the role of the FDI in contributing to the economic growth of the host economy, the government of NZ developed liberal FDI policies with few restrictions thus facilitating FDI inflows from different parts of the world. A recent study by the New Zealand Institute of Economic Research (NZIER, 2016) highlighted the need for the NZ economy to attract FDI given its low capital base. Several macro level factors influence the level of FDI in the host country such as, the market size, tax rates and government policies (Lee \& Yeo, 2016). Most of the FTAs or similar agreements with other countries reflect a country's open, transparent trade and investment policies, resulting in significant growth in trade and investment flows.

This paper investigates NZ's trade and investment growth with selected APEC member economies to find out whether the growth in trade and investment is spread across the countries in the region or concentrated in one or few countries.

\section{Methodology}

Trade Intensity Index $\left(I_{i j}\right)$ for country i's exports to country $j$ is defined as the share of county $j$ in country i's total exports $\left(X_{i j} / X_{i}\right)$ relative to the share of $j$ 's imports $\left(M_{j}\right)$ in total world imports, net of i's imports $\left(M_{w}-M_{i}\right)$.

$$
\mathrm{I}_{\mathrm{ij}}=\left(\mathrm{X}_{\mathrm{ij}} / \mathrm{X}_{\mathrm{i}}\right) /\left(\mathrm{M}_{\mathrm{j}} /\left(\mathrm{M}_{\mathrm{w}}-\mathrm{M}_{\mathrm{i}}\right)\right)
$$

The term $\mathrm{M}_{\mathrm{i}}$ is deducted from the denominator to take into account that a country does not import to or export from itself. A value of the index greater than unity indicates that country i trades with country $j$ more intensely than does the world as a whole. A value of less than unity indicates a small flow of trade between $\mathrm{i}$ and $\mathrm{j}$ relative to j's trade with the rest of the world (Braga 1994; Faezeh 1998).

The FDI index measures the intensity of FDI relationship between two countries i.e. the home country $(i)$ and the host country $(j)$. The FDI index uses a ratio that compares the actual value of the FDI stock of country $i$ in country $j$ with the expected value of the FDI stock of country $i$ in country $j$ given the world position of each of them as home and host countries respectively. 


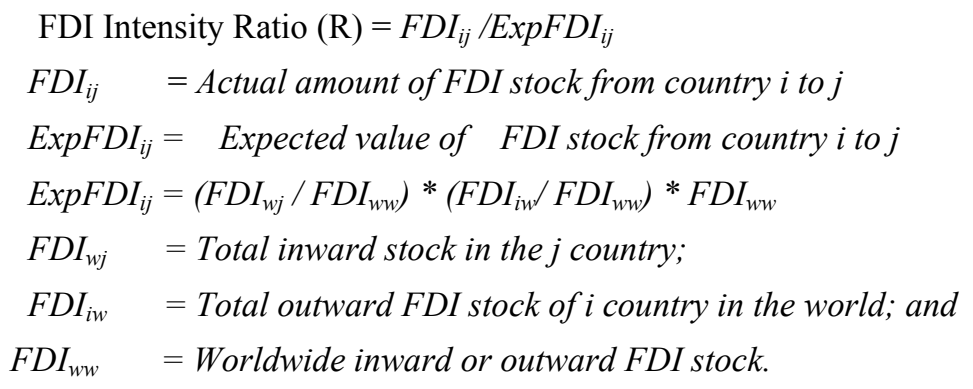

If the intensity ratio is greater than unity, the FDI relationship is stronger than would be expected based on the relative importance of the two economies as home and host, less than unity implies weaker than expected.

(UNCTAD, 2007)

\section{Results and Discussion}

The Trade Intensity Ratios (TIRs) are presented in Table 2. Although the seven countries accounted for about 55\% of the total trade flows, the trade intensity ratio with Australia is several times higher than the rest of the countries with an average ratio of 15.04. This is followed by Japan (1.57), and China 1.03). This is a reflection of the significance of the Australian market to the New Zealand exporters. Japan, and China are the two other countries where the average ratio exceeds unity implying that the trade intensity with these countries is significant albeit less than with Australia. In the recent past the absolute ratio with Australia has decreased from 19.95 in 2012 to 14.70 in 2015 where as the ratio with China has been gradually increasing from 1.29 in 2012 to 1.75 indicating the growing importance of China in NZ's external trade. The increase trade can be attributed to the FTA signed between the two countries in 2008. Japan is the other country with a trade intensity ratio of greater than unity. However, there has been a decline in the absolute ratio from 2.11 in 2001 to 1.48 in 2006 and has been below 2.00 ever since. The TIRs with Hong Kong, Singapore, and the USA have always been less than unity although these countries are considered to be NZ's major trading partners.

Table 2. Trade intensity ratios 2001-2015

\begin{tabular}{|c|c|c|c|c|c|c|}
\hline Year/Country & Australia & China & $\begin{array}{l}\text { Hong } \\
\text { Kong }\end{array}$ & Japan & Singapore & $U S A$ \\
\hline 2001 & 18.14 & 1.02 & 0.72 & 2.11 & 0.64 & 0.63 \\
\hline 2002 & 17.09 & 0.97 & 0.61 & 2.10 & 0.69 & 0.67 \\
\hline 2003 & 17.46 & 0.84 & 0.62 & 2.06 & 0.59 & 0.69 \\
\hline 2004 & 16.54 & 0.88 & 0.60 & 2.16 & 0.62 & 0.73 \\
\hline 2005 & 16.49 & 0.75 & 0.57 & 2.03 & 0.71 & 0.71 \\
\hline 2006 & 12.29 & 0.56 & 0.42 & 1.48 & 0.57 & 0.48 \\
\hline 2007 & 12.80 & 0.53 & 0.44 & 1.46 & 0.73 & 0.48 \\
\hline 2008 & 13.43 & 0.59 & 0.50 & 1.28 & 0.76 & 0.48 \\
\hline 2009 & 12.12 & 0.76 & 0.51 & 1.14 & 1.03 & 0.48 \\
\hline 2010 & 12.37 & 0.79 & 0.49 & 1.19 & 0.67 & 0.48 \\
\hline 2011 & 15.71 & 1.15 & 0.57 & 1.44 & 0.82 & 0.57 \\
\hline 2012 & 19.95 & 1.29 & 0.58 & 1.31 & 0.83 & 0.60 \\
\hline 2013 & 12.77 & 1.59 & 0.42 & 1.14 & 0.95 & 0.52 \\
\hline 2014 & 13.90 & 1.66 & 0.43 & 1.26 & 0.99 & 0.62 \\
\hline 2015 & 14.70 & 1.75 & 0.56 & 1.42 & 0.82 & 0.57 \\
\hline Average & 15.04 & 1.03 & 0.53 & 1.57 & 0.76 & 0.58 \\
\hline
\end{tabular}

Source: Own calculations based on data sourced from Statistics NZ, and UN COMTRADE. 
An examination of the FDI intensity ratios (Table 3), reveals Australia's domination in this area as well. The FDI relationship between these two countries is the strongest compared to other major trading partners. The average FDI intensity ratio for the study period stands at 23.43 which is several times higher than the average ratios of the other countries. The only country with an FDI ratio of greater than unity is Singapore with an average ratio of 1.34 .

This pattern highlights the extent of bilateralism as reflected by the dominance of Australian investment in NZ. Some of the underlying reasons include the comprehensive FTA i.e. ANZCER, geographical proximity, similarities in legal, economic, political and cultural environment.

Table 3. FDI intensity ratios 2001-2015

\begin{tabular}{lllllll}
\hline Year/Country & Australia & China & Hong Kong & Japan & Singapore & USA \\
\hline 2001 & 33.62 & 1.09 & 0.32 & 0.57 & 2.73 & 0.77 \\
\hline 2002 & 24.13 & 0.39 & 0.38 & 0.57 & 2.69 & 0.74 \\
\hline 2003 & 19.59 & 0.87 & 0.34 & 0.55 & 1.45 & 0.48 \\
\hline 2004 & 17.33 & 0.97 & 0.31 & 0.60 & 1.25 & 0.39 \\
\hline 2005 & 23.27 & 0.39 & 0.24 & 0.70 & 1.32 & 0.43 \\
\hline 2006 & 22.62 & 0.19 & 0.19 & 0.72 & 0.76 & 0.37 \\
\hline 2007 & 21.68 & -1.35 & 0.15 & 0.71 & 0.89 & 0.37 \\
\hline 2008 & 36.52 & 0.00 & 0.22 & 0.69 & 1.50 & 0.84 \\
\hline 2009 & 23.03 & 0.11 & 0.25 & 0.68 & 1.20 & 0.55 \\
\hline 2010 & 20.27 & 0.05 & 0.28 & 0.60 & 0.42 & 0.48 \\
\hline 2011 & 20.57 & 0.06 & 0.19 & 0.62 & 0.83 & 0.47 \\
\hline 2012 & 19.90 & 0.08 & 0.17 & 0.57 & 0.86 & 0.39 \\
\hline 2013 & 22.06 & 0.12 & 0.25 & 0.54 & 1.37 & 0.32 \\
\hline 2014 & 23.36 & 0.18 & 0.40 & 0.58 & 1.31 & 0.25 \\
\hline 2015 & 23.48 & 0.20 & 0.36 & 0.56 & 1.42 & 0.31 \\
\hline Average & 23.43 & 0.20 & 0.27 & 0.62 & 1.34 & 0.48 \\
\hline
\end{tabular}

Source: Own calculations based on data sourced from Statistics NZ, and UNCTAD.

\section{Conclusion}

The analysis of NZ's trade and FDI intensities with its major trading partners reveals that bilateralism is a dominant feature of NZ's external trade and inward investment. NZ's six major trading partners, who are also members of the APEC forum, accounted for 52\% trade flows, and 76\% of FDI stock in 2015, reflecting the importance of this region to NZ's economy. Within the region, Australia's dominance is clearly evident as it accounted for $17.6 \%$ of NZ's total trade flows, and 52\% of FDI stock in 2015, substantially higher than the other key trading partners, indicating the extent of NZ's dependence on Australia for trade and investment. A conclusion that can be drawn is that the bilateral FTA between NZ, and Australia i.e. the ANZCER, and their APEC membership has been contributing to the growth in trade and investment relations between these two countries. In view of the risks associated with too much dependence on a single market, NZ has been trying to diversify and gain access to other markets. The FTA with China negotiated in 2008 has a positive impact on the total trade between the two countries which has increased from $5.3 \%$ in 2001 to $16.1 \%$ by 2015 . Since NZ has also negotiated FTAs with other countries such as Malaysia, Thailand, and Korea, in future there is a possibility of enhanced trade and investment diversification in the region, thus reducing the degree of bilateralism between NZ, and Australia. In future, once the data is available, further research can be done to find out whether NZ's trade and FDI are more evenly spread across the Asia-Pacific region rather than heavily concentrated in one or two markets. 


\section{References}

Baldwin, R., \& Carpenter, T. (2010). A 3-BLOC DANCE: EAST ASIAN REGIONALISM AND THE NORTH ATLANTIC TRADE GIANTS. The Singapore Economic Review, 55(1), 27-47. https://doi.org/10.1142/S0217590810003596

Braga, C. A. P, Safadi, R., \& Yeats, A. (1994). Regional integration in the Americas: De ja vu all over again?. World Economy, 17(4), 571-601. https://doi.org/10.1111/j.1467-9701.1994.tb00842.x

Dairy Companies Association of New Zealand. (2016). Retrieved from http://www.dcanz.com/about-nz-dairy-industry/dairying-today

Dent, C. M. (2013). Paths ahead for East Asia and Asia-Pacific Regionalism. International Affairs, 89(4), 963-985. https://doi.org/10.1111/1468-2346.12054

Faezeh, F. (1998). Does Membership in a Regional Preferential Trade Arrangement Make A Country More or Less Protectionist?. World Economy, 21(3).

Hassan, M., \& Nassar, R. (2016). Empirical Investigation of the Relationship Between Nafta and Key Economic Variables in Mexico. Journal of International Business Disciplines, 11(2).

KPMG. (2015). Foreign Direct Investment in New Zealand: Trends and Insights. Retrieved from https://assets.kpmg.com/content/dam/kpmg/pdf/2015/08/KPMG-Foreign-Direct-Investment-analysis-Augus t-2015.pdf

Lattimore, R., Kowalski, P., \& Hawke, G. (2009). New Zealand's patterns of comparative advantage. NZ Trade Consortium working paper, 46, NZIER. Retrieved from https://nzier.org.nz/publication/new-zealand039s-patterns-of-comparative-advantage

Lee, C., Lee, C. G., \& Yeo. M. (2016). Determinants of Singapore's Outward FDI. Journal of Southeast Asian Economies. 33(I). https://doi.org/10.1353/ase.2016.0012

Michaely, M. (2014). Regionalism in Trade: An Overview of the Last Half-Century. Global Economy Journal, 14(3-4), 425-434. https://doi.org/10.1515/gej-2014-0031

Ministry of Foreign Affairs and Trade. Government of New Zealand. Retrieved from https://www.mfat.govt.nz/assets/_securedfiles/FTAs-agreements-in-force/Australia/anzcer-cep-booklet.pdf

New Zealand Institute of Economic Research. (2016). Foreign Direct Investment in New Zealand: A brief review of the pros and cons. Retrieved from https://nzier.org.nz/static/media/filer_public/17/06/1706e6f6-16fa-4c3f-ba40-2ba4e75df2fd/foreign_direct_i nvestment_in_nz.pdf

OECD. (2015). OECD Economic Surveys: New Zealand 2015. Retrieved from http://www.oecd-ilibrary.org/economics/oecd-economic-surveys-new-zealand-2015_eco_surveys-nzl-2015en

Statistics New Zealand. (2015). Global New Zealand. Retrieved from http://www.stats.govt.nz/browse_for_stats/industry_sectors/imports_and_exports/global-nz-jun-15.aspx

UNCTAD. (2007). World Investment Report. Retrieved from http://unctad.org/en/Docs/wir2007_en.pdf

Vitalis, V. (2009). Domestic Reform, Trade, Innovation and Growth in New Zealand's Agricultural Sector. OECD Journal: General Papers, 2008(4). https://doi.org/10.1787/gen_papers-v2008-art28-en

Wang.J. (2011, September). China and East Asian Regionalism. European Law Journal, 17(5), 611-629. https://doi.org/10.1111/j.1468-0386.2011.00569.x

\section{Copyrights}

Copyright for this article is retained by the author(s), with first publication rights granted to the journal.

This is an open-access article distributed under the terms and conditions of the Creative Commons Attribution license (http://creativecommons.org/licenses/by/4.0/). 